\title{
Short-term efficacy after switching from adefovir dipivoxil and tenofovir disoproxil fumarate therapy to tenofovir alaferamide for chronic hepatitis B
}

\author{
TOMOYA SANO $^{1}$, KEISUKE AMANO ${ }^{1}$, TATSUYA IDE ${ }^{1}$, TOSHIHIRO KAWAGUCHI ${ }^{1}$, REIICHIRO KUWAHARA ${ }^{1}$, \\ TERUKO ARINAGA-HINO ${ }^{1}$, HIRONORI KOGA ${ }^{1,2}$, RYOKO KUROMATSU $^{1}$ and TAKUJI TORIMURA ${ }^{1,2}$ \\ ${ }^{1}$ Division of Gastroenterology, Department of Internal Medicine, Kurume University School of Medicine, \\ ${ }^{2}$ Division of Liver Cancer Research, Research Center for Innovative Cancer Therapy, \\ Kurume University School of Medicine, Kurume, Fukuoka 830-0011, Japan
}

Received July 20, 2020; Accepted October 29, 2020

DOI: $10.3892 /$ br.2020.1388

\begin{abstract}
The aim of the present study was to evaluate the effects of switching to tenofovir alafenamide (TAF) in patients who had received a nucleos(t)ide analog (NA) for the treatment of chronic hepatitis B (CHB). The data from 33 Japanese patients with $\mathrm{CHB}$ who received TAF therapy after using NA [adefovir dipivoxil (ADV) and/or tenofovir disoproxil fumarate (TDF)] were retrospectively analyzed. Specifically, the biochemical and virological markers from the start of the TAF treatment to 6 months later were assessed. Comparative evaluation was performed by dividing patients into two groups: Long-term $(n=19)$ and short-term administration groups $(n=14)$, with a cutoff administration duration of 10 years. In all 33 patients, the levels of serum hepatitis B surface antigen (HBsAg; $1,126 \pm 1,724$ to $1,001 \pm 1,591 \mathrm{IU} / \mathrm{ml} ; \mathrm{P}<0.0001$ ), serum alkaline phosphatase (ALP) $(320 \pm 126$ to $283 \pm 124 \mathrm{U} / 1$; $\mathrm{P}=0.028)$, serum bone specific alkaline phosphatase $(19.7 \pm 9.0$ to $17.7 \pm 8.0 \mu \mathrm{g} / \mathrm{l} ; \mathrm{P}=0.0006)$ and urine $\beta 2$-microglobulin-creatinine ratio (U-BMG/Cr; $5,224 \pm 17,471$ to $3,547 \pm 14,652 \mu \mathrm{g} / \mathrm{g} \cdot \mathrm{Cre}$; $\mathrm{P}=0.002)$ significantly decreased from baseline after 6 months. Serum HBsAg, serum ALP and U-BMG/Cr showed a significant
\end{abstract}

Correspondence to: Dr Tomoya Sano, Division of Gastroenterology, Department of Internal Medicine, Kurume University School of Medicine, 67 Asahi-Machi, Kurume, Fukuoka 830-0011, Japan E-mail: sano_tomoya@med.kurume-u.ac.jp

Abbreviations: ADV, adefovir dipivoxil; $\mathrm{CHB}$, chronic hepatitis $\mathrm{B}$; CKD, chronic kidney disease; ETV, entecavir; GFR, glomerular filtration rate; HBV, hepatitis $\mathrm{B}$ virus; $\mathrm{HCC}$, hepatocellular carcinoma; HIV, human immunodeficiency virus; LAM, lamivudine; $\mathrm{NAs}$, nucleos(t)ide analogs; $\mathrm{HBeAb}$, hepatitis B e antibody; $\mathrm{HBeAg}$, hepatitis B e antigen; HBsAg, serum hepatitis B surface antigen; TFV, tenofovir; TAF, tenofovir alafenamide; TDF, tenofovir disoproxil fumarate; Tmp/GFR, tubular maximum for phosphate corrected for the GFR; TRP, tubular reabsorption of phosphate

Key words: adefovir dipivoxil, hepatitis $\mathrm{B}$ virus, tenofovir alafenamide, tenofovir disoproxil fumarate reduction in both groups. In conclusion, switching from ADV or TDF to TAF resulted in a decrease in serum HBsAg and improvement in serum ALP and U-BMG/Cr after 6 months of treatment in patients regardless of history of treatment with NA.

\section{Introduction}

Hepatitis B virus (HBV) infection is the most common chronic viral infection worldwide, infecting $\sim 2$ billion individuals, of which $>350$ million are chronic HBV carriers (1). The development of nucleos(t)ide analogs (NAs) has revolutionized the management of chronic hepatitis $\mathrm{B}(\mathrm{CHB})$ in the last two decades (2). At present, five NAs have been approved as antiviral therapies for CHB in Japan. These agents are classified according to their chemical structures: Two nucleoside analogs that include lamivudine (LAM) and entecavir (ETV), two nucleotide analogs that include adefovir dipivoxil (ADV) and tenofovir disoproxil fumarate (TDF) (3), and the newly approved tenofovir alafenamide (TAF) (4-6). NAs are known to effectively suppress HBV replication and reduce the risk of disease progression and hepatic events (7). Long-term NA treatment has demonstrated effectiveness in improving histological findings and reducing the incidence of hepatocellular carcinoma (HCC) $(8,9)$. Although NAs are generally safe and comparatively free of major side effects (10), renal and bone toxicity may occur in a small yet significant proportion of patients receiving older generation NAs, for example, ADV and TDF (11). Given the high number of patients receiving NAs worldwide, even a small risk of any of these toxicities can be translated into a major medical issue. TAF was approved in Japan for HBV treatment in 2017 (12). Both TAF and TDF are phosphonamidite prodrugs of tenofovir (TFV) that share the same intracellular active metabolite, TFV diphosphate, which is effective against both HBV and human immunodeficiency virus (HIV)-1 infection $(13,14)$. TAF has greater plasma stability, which allows for more efficient uptake by hepatocytes at lower plasma concentrations than TDF; thus, the circulating concentration of TFV is $90 \%$ lower after administration of a $25 \mathrm{mg}$ dose of TAF than after a $300 \mathrm{mg}$ dose of TDF (15). This difference likely contributes to the relatively better safety 
profile of TAF compared with TDF, particularly for renal and bone dysfunction. TAF was shown to have less influence on the glomerular filtration rate (GFR) and renal tubule function than TDF in international phase III trials (4-6). Long-term use of ADV and TDF has been reported, and there are several cases where renal and tubular dysfunction and bone metabolism abnormalities occurred (16-19). At present, few studies have reported the effect of switching to TAF after long-term use of other NAs (particularly the nucleotide group). Thus, the present study aimed to evaluate the effect of TAF (particularly on renal and tubular function) in patients with $\mathrm{CHB}$ who had received NA treatment.

\section{Materials and methods}

Patients. The present retrospective, single-center study included patients with chronic HBV infection. A total of 33 consecutive adult Japanese patients (mean age $61.5 \pm 8.7$ years; 23 males and 10 females) who received TAF-based monotherapy (Vemlidy; Gilead Sciences KK) or a combination rescue therapy (including LAM and ETV combined) after using ADV and/or TDF between May 2017 and March 2019 at Kurume University Hospital were recruited. The exclusion criteria were as follows: i) Co-infection with HIV-1 or hepatitis C virus; ii) other liver diseases such as autoimmune hepatitis, alcoholic liver disease or metabolic liver disease; iii) decompensated cirrhosis; and iv) terminal illness.

This study was performed in accordance with the ethical principles described in the Declaration of Helsinki (20) and was approved by the Clinical Research Ethics Committee of Kurume University Hospital (approval no. 17209). Written informed consent was obtained from all patients.

Standard doses of LAM (100 mg/day), ADV (10 mg/day), ETV (0.5 mg/day), TDF (300 mg/day) and TAF (25 mg/day) were administered. The dosing interval of ADV and TDF was modified by the attending physician (once every 2 days) when the estimated GFR (eGFR) decreased to $50 \mathrm{ml} / \mathrm{min} / 1.73 \mathrm{~m}^{2}$ or lower.

Study design. Biochemical (particularly renal tubular function and phosphorus metabolism) and virological markers were assessed at the start of TAF administration and 3 and 6 months after switching in all 33 cases. The patients were divided into two groups: Long-term NA administration $(n=19)$ and short-term NA administration $(n=14)$.

In Japan, NA compounds received insurance approvals at different times: LAM in 2000, ADV in 2004, ETV in 2006 (21), TDF in 2014, and TAF in 2017. Reflecting on the above grouping, all patients who received NA treatment for $\geq 10$ years were introduced with LAM and were included in the long-term group. Conversely, all patients who received NA therapy for $<10$ years were treated with an NA other than LAM and were included in the short-term group. Changes in biological and virological markers were compared between the two groups.

Data collection. All available medical records were evaluated thoroughly. Body mass index was calculated as weight $(\mathrm{kg})$ divided by the square of height $(\mathrm{m})$. Hypertension was defined as a clinical systolic blood pressure $\geq 140 \mathrm{mmHg}$ and/or clinical diastolic blood pressure $\geq 90 \mathrm{mmHg}$, or the use of antihypertensive agents. Diabetes mellitus was diagnosed if the fasting blood glucose levels were $>126 \mathrm{mg} / \mathrm{dl}$ or the HbA1c levels were $>6.9 \%$, according to the Diagnostic Criteria for Diabetes Mellitus (22) or by the documented use of antidiabetic agents or insulin. Blood and urine samples were collected in the morning after an overnight fast. The renal function was assessed by calculating the eGFR using the chronic kidney disease (CKD) epidemiology collaboration formula (23). The renal tubular function was assessed using a urine $\mathrm{N}$-acetyl- $\beta$-D-glucosaminidase-creatinine ratio and urine $\beta 2$-microglobulin-creatinine (U-BMG/Cr) ratio. The tubular metabolism of phosphates was assessed using a tubular maximum for phosphate corrected for the GFR (TmP/GFR) and tubular reabsorption of phosphate (TRP). TRP was calculated using the following formula: TRP=(1-urine phosphate/urine creatinine) $x$ (serum creatinine/serum phosphate). The formula used to calculate TmP/GFR is dependent on the value of TRP and can be calculated using the following formulas: If TRP is $\leq 0.86$, then TmP/GFR=TRP $\mathrm{x}$ serum phosphate; if TRP is $>0.86$, then $\mathrm{TmP} / \mathrm{GFR}=0.3 \mathrm{x} \mathrm{TRP} /(1-0.8 \mathrm{x} \mathrm{TRP}) \mathrm{x}$ serum phosphate (24).

Serum viral markers. The serum hepatitis B surface antigen (HBsAg) levels were determined using a chemiluminescence immunoassay (LUMIPULSE G1200 HBsAg-HQ assay kit; Fujirebio Inc.); the lower limit of detection was $0.005 \mathrm{IU} / \mathrm{ml}$. The serum HBV DNA levels were determined using real-time TaqMan PCR assay (Cobas Taqman HBV test, Auto v2.0 kit, Roche Diagnostics, K.K); the lower limit of detection was $2.1 \log _{\text {copies } / m l}$. The serum hepatitis B e antigen $(\mathrm{HBeAg})$ and hepatitis $\mathrm{B}$ e antibody $(\mathrm{HBe} \mathrm{Ab})$ levels were determined using a chemiluminescence enzyme immunoassay (Architect HBeAg; $\mathrm{HBeAb}$ assay kit; Abbott Laboratory; cat. no. 6C32).

Statistical analysis. All data are presented as the mean \pm standard deviation or as percentages. Differences between groups were compared using a $\chi^{2}$ test or a Mann-Whitney U test, where appropriate. All statistical analyses were performed using JMP Pro version 13 (SAS Institute). $\mathrm{P}<0.05$ was considered to indicate a statistically significant difference.

\section{Results}

Baseline characteristics. Table I lists the baseline clinical and laboratory characteristics at the start of TAF therapy. In addition, Table SI lists the treatment history with NAs in all cases. The mean age of all patients was $61.5 \pm 8.7$ years, and the majority of patients were male (70\%). Moreover, $9(27 \%)$ patients had arterial hypertension and $5(15 \%)$ had diabetes mellitus. The mean duration of NA treatment was $11.2 \pm 6.3$ years. A total of 21 patients $(64 \%)$ had a history of ADV and $24(73 \%)$ had a history of TDF treatment. The mean total duration of ADV treatment was 9.8 \pm 3.0 years, and the mean total duration of TDF treatment was $2.0 \pm 0.8$ years. A total of 32 (97\%) patients had chronic hepatitis and ADV had been administered for $\sim 10$ years. In addition, the backgrounds of the long-term and short-term administration groups were compared. A significant difference was observed between the administration periods of total NA (16.1 \pm 2.4 vs. $4.6 \pm 2.7$ years; $\mathrm{P}<0.001)$ and ADV (10.5 \pm 2.1 vs. $3.3 \pm 0.4 ; \mathrm{P}=0.027)$. Similarly, the rates of NA treatment history were different. Most patients 
Table I. Baseline characteristics of patients receiving NA treatment.

\begin{tabular}{|c|c|c|c|c|}
\hline Parameter ${ }^{\mathrm{c}}$ & $\begin{array}{l}\text { Total, } \\
n=33\end{array}$ & $\begin{array}{l}\text { Long-term } \\
\text { group, } n=19\end{array}$ & $\begin{array}{l}\text { Short-term } \\
\text { group, } n=14\end{array}$ & P-value ${ }^{d}$ \\
\hline Age, years, & $62 \pm 9$ & $61 \pm 10$ & $62 \pm 9$ & 0.9564 \\
\hline Male: & $23(70 \%):$ & $13(68 \%):$ & $10(71 \%):$ & 1.0000 \\
\hline female $(\%)$ & $10(30 \%)$ & $6(32 \%)$ & $4(29 \%)$ & \\
\hline $\mathrm{BMI}, \mathrm{kg} / \mathrm{m}^{2}$ & $21.8 \pm 2.9$ & $21.7 \pm 2.3$ & $22.0 \pm 3.6$ & 0.7987 \\
\hline With cirrhosis & $1(3 \%)$ & $1(5 \%)$ & $0(0 \%)$ & 1.0000 \\
\hline With hypertension & $9(27 \%)$ & $2(11 \%)$ & $7(50 \%)$ & $0.0191^{\mathrm{a}}$ \\
\hline With diabetes mellitus & $5(15 \%)$ & $3(16 \%)$ & $2(14 \%)$ & 1.0000 \\
\hline \multicolumn{5}{|l|}{ Latest NA regimen for TAF-based therapy n (\%) } \\
\hline ADV single & $1(3 \%)$ & $1(5 \%)$ & $0(0 \%)$ & 1.0000 \\
\hline TDF single & $11(33 \%)$ & $2(11 \%)$ & $9(64 \%)$ & $0.0023^{\mathrm{a}}$ \\
\hline LAM single & $0(0 \%)$ & $0(0 \%)$ & $0(0 \%)$ & \\
\hline ETV single & $0(0 \%)$ & $0(0 \%)$ & $0(0 \%)$ & \\
\hline $\mathrm{ADV}+\mathrm{LAM}$ & $6(18 \%)$ & $6(32 \%)$ & $0(0 \%)$ & $0.0272^{\mathrm{a}}$ \\
\hline $\mathrm{ADV}+\mathrm{ETV}$ & $2(6 \%)$ & $1(5 \%)$ & $1(7 \%)$ & 1.0000 \\
\hline $\mathrm{TDF}+\mathrm{LAM}$ & $7(21 \%)$ & $7(37 \%)$ & $0(0 \%)$ & $0.0126^{\mathrm{a}}$ \\
\hline $\mathrm{TDF}+\mathrm{ETV}$ & $6(18 \%)$ & $2(11 \%)$ & $4(29 \%)$ & 0.3631 \\
\hline \multicolumn{5}{|c|}{ Past NA treatment before TAF-based therapy, n (\%) } \\
\hline ADV & $21(64 \%)$ & $19(100 \%)$ & $2(14 \%)$ & $<0.0001^{\mathrm{b}}$ \\
\hline $\mathrm{TDF}$ & $24(73 \%)$ & $11(58 \%)$ & $13(93 \%)$ & 0.0466 \\
\hline LAM & $19(58 \%)$ & $19(100 \%)$ & $0(0 \%)$ & $<0.0001^{\mathrm{b}}$ \\
\hline ETV & $12(36 \%)$ & $3(16 \%)$ & $9(64 \%)$ & 0.0091 \\
\hline Duration of all NA treatments, years & $11.2 \pm 6.3$ & $16.1 \pm 2.4$ & $4.6 \pm 2.7$ & $<0.001^{\mathrm{b}}$ \\
\hline \multicolumn{5}{|l|}{ Duration of prior NA treatment, years } \\
\hline ADV & $9.8 \pm 3.0$ & $10.5 \pm 2.1$ & $3.3 \pm 0.4$ & $0.027^{\mathrm{a}}$ \\
\hline TDF & $2.0 \pm 0.8$ & $1.8 \pm 0.8$ & $2.2 \pm 0.8$ & 0.2124 \\
\hline LAM & $13.5 \pm 4.0$ & $13.5 \pm 4.0$ & 0 & $<0.0001^{\mathrm{b}}$ \\
\hline ETV & $4.7 \pm 2.8$ & $4.8 \pm 3.8$ & $4.7 \pm 2.6$ & 1.0000 \\
\hline HBeAg-positive & $11(33 \%)$ & $3(33 \%)$ & $8(57 \%)$ & $0.0240^{\mathrm{a}}$ \\
\hline HBV DNA positive, $>1.3 \mathrm{Log} \mathrm{IU} / \mathrm{ml}, \mathrm{n}(\%)$ & $0(0 \%)$ & $0(0 \%)$ & $0(0 \%)$ & \\
\hline $\mathrm{HBsAg}, \mathrm{IU} / \mathrm{ml}$ & $1,126 \pm 1,724$ & $590 \pm 641$ & $1,853 \pm 2,400$ & 0.0974 \\
\hline AST, U/l & $24.9 \pm 7.7$ & $25.5 \pm 9.5$ & $24.1 \pm 4.3$ & 0.7288 \\
\hline ALT, U/1 & $23.1 \pm 11.1$ & $24.6 \pm 13.5$ & $21.1 \pm 6.4$ & 0.8695 \\
\hline ALP, U/1 & $320 \pm 126$ & $324 \pm 141$ & $298 \pm 86$ & 0.7021 \\
\hline $\mathrm{BAP}, \mu \mathrm{g} / \mathrm{l}$ & $19.7 \pm 9.0$ & $21.1 \pm 11.0$ & $17.9 \pm 5.1$ & 0.6358 \\
\hline Total bilirubin, mg/dl & $0.9 \pm 0.3$ & $0.9 \pm 0.3$ & $0.9 \pm 0.4$ & 0.8979 \\
\hline Platelets, $\times 10^{3} / \mathrm{mm}^{3}$ & $189 \pm 60$ & $183 \pm 63$ & $197 \pm 58$ & 0.5599 \\
\hline Creatinine, mg/dl & $0.8 \pm 0.2$ & $0.9 \pm 0.3$ & $0.8 \pm 0.2$ & 0.2743 \\
\hline $\mathrm{eGFR}, \mathrm{ml} / \mathrm{min} / 1.73 \mathrm{~m}^{2}$ & $73.4 \pm 13.7$ & $68.4 \pm 17.5$ & $77.9 \pm 18.1$ & 0.1837 \\
\hline Serum Ca, mmol/l & $9.3 \pm 0.4$ & $9.4 \pm 0.4$ & $9.3 \pm 0.2$ & 0.3158 \\
\hline Serum P, mmol/1 & $3.1 \pm 0.5$ & $3.1 \pm 0.6$ & $3.1 \pm 0.5$ & 0.9274 \\
\hline $\mathrm{U}-\mathrm{BMG} / \mathrm{Cr}, \mu \mathrm{g} / \mathrm{g} \cdot \mathrm{Cre}$ & $5,224 \pm 17,471$ & $8,636 \pm 23,026$ & $951 \pm 1,455$ & 0.0558 \\
\hline U-NAG/Cr, U/g.Cre & $9.2 \pm 8.9$ & $10.8 \pm 11.5$ & $7.2 \pm 3.1$ & 0.8698 \\
\hline$\% \mathrm{TRP}, \%$ & $85.0 \pm 9.3$ & $82.5 \pm 11.4$ & $88.1 \pm 4.5$ & 0.1719 \\
\hline TmP/GFR, mg/dl & $2.6 \pm 0.6$ & $2.6 \pm 0.7$ & $2.7 \pm 0.5$ & 0.5478 \\
\hline
\end{tabular}

${ }^{\mathrm{a}} \mathrm{P}<0.05,{ }^{\mathrm{b}} \mathrm{P}<0.001 .{ }^{\mathrm{c}}$ Data are presented as the mean \pm standard deviation or $\mathrm{n}(\%) .{ }^{\mathrm{d}} \mathrm{P}$-values are for the comparison between the long-term and short-term groups. ADV, adefovir dipivoxil; ALP, alkaline phosphatase; ALT, alanine aminotransferase; AST, aspartate aminotransferase; BAP, bone specific alkaline phosphatase; BMI, body mass index; eGFR, estimated glomerular filtration rate; ETV, entecavir; HBeAg, hepatitis B e antigen; HBsAg, hepatitis B surface antigen; HBV, hepatitis B virus; LAM, lamivudine; NA, nucleos(t)ide analogs; TAF, tenofovir alafenamide; TDF, tenofovir disoproxil fumarate; TmP/GFR, tubular maximum for phosphate corrected for the glomerular filtration rate; TRP, tubular reabsorption of phosphate; $\mathrm{U}-\mathrm{BMG} / \mathrm{Cr}$, urine $\beta 2$-microglobulin-creatinine ratio; $\mathrm{U}-\mathrm{NAG} / \mathrm{Cr}$, urine $\mathrm{N}$-acetyl- $\beta$-D-glucosaminidase-creatinine ratio. 
Table II. Time course observation of virological markers and hepatobiliary enzyme levels.

\begin{tabular}{|c|c|c|c|c|}
\hline Parameters $^{\mathrm{d}}$ & Baseline & 3 months & 6 months & P-value \\
\hline \multicolumn{5}{|l|}{ Total, $n=33$} \\
\hline HBeAg-positive & $11(33 \%)$ & $10(30 \%)$ & $10(30 \%)$ & 1.0000 \\
\hline HBV DNA positive, $>1.3 \mathrm{Log} \mathrm{IU} / \mathrm{ml}$ & $0(0 \%)$ & $0(0 \%)$ & $0(0 \%)$ & \\
\hline HBsAg, IU/ml & $1,126 \pm 1,724$ & $1,032 \pm 1,648$ & $1,001 \pm 1,591$ & $0.0001^{\mathrm{c}}$ \\
\hline AST, U/1 & $24.9 \pm 7.7$ & $23.5 \pm 6.6$ & $26.6 \pm 14.2$ & 0.7459 \\
\hline ALT, U/1 & $23.1 \pm 11.1$ & $22.6 \pm 12.4$ & $24.5 \pm 14.5$ & 0.5044 \\
\hline ALP, U/1 & $320 \pm 126$ & $295 \pm 135$ & $283 \pm 124$ & $0.028^{\mathrm{a}}$ \\
\hline $\mathrm{BAP}, \mu \mathrm{g} / 1$ & $19.7 \pm 9.0$ & N/A & $17.7 \pm 8.0$ & $0.0006^{\mathrm{c}}$ \\
\hline Total bilirubin, mg/dl & $0.9 \pm 0.3$ & $0.9 \pm 0.3$ & $0.9 \pm 0.3$ & 0.9821 \\
\hline \multicolumn{5}{|l|}{ Long-term group, $n=19$} \\
\hline HBsAg IU/ml & $590 \pm 641$ & $523 \pm 613$ & $537 \pm 598$ & $0.0108^{\mathrm{a}}$ \\
\hline AST, U/1 & $25.5 \pm 9.5$ & $23.9 \pm 6.7$ & $24.0 \pm 7.1$ & 0.2982 \\
\hline ALT, U/l & $24.6 \pm 13.5$ & $23.5 \pm 15.3$ & $22.2 \pm 12.4$ & 0.1329 \\
\hline ALP, U/1 & $324 \pm 141$ & $310 \pm 159$ & $302 \pm 151$ & $0.0281^{\mathrm{a}}$ \\
\hline $\mathrm{BAP}, \mu \mathrm{g} / 1$ & $21.1 \pm 11.0$ & N/A & $19.2 \pm 9.7$ & 0.0678 \\
\hline Total bilirubin, mg/dl & $0.9 \pm 0.3$ & $0.9 \pm 0.3$ & $0.9 \pm 0.3$ & 0.1221 \\
\hline \multicolumn{5}{|l|}{ Short-term group, $n=14$} \\
\hline HBsAg, IU/ml & $1,853 \pm 2,400$ & $1,796 \pm 2,350$ & $1,631 \pm 2,235$ & $0.004^{\mathrm{b}}$ \\
\hline AST, U/1 & $24.1 \pm 4.3$ & $23.0 \pm 6.6$ & $30.1 \pm 20.2$ & 0.4121 \\
\hline ALT, U/1 & $21.1 \pm 6.4$ & $21.2 \pm 6.1$ & $27.6 \pm 16.9$ & 0.5093 \\
\hline ALP, U/1 & $298 \pm 86$ & $255 \pm 73$ & $257 \pm 69$ & $0.005^{\mathrm{b}}$ \\
\hline $\mathrm{BAP}, \mu \mathrm{g} / 1$ & $17.9 \pm 5.1$ & N/A & $15.5 \pm 4.6$ & $0.0016^{\mathrm{b}}$ \\
\hline Total bilirubin, mg/dl & $0.9 \pm 0.4$ & $0.9 \pm 0.4$ & $0.9 \pm 0.3$ & 0.1016 \\
\hline
\end{tabular}

${ }^{\mathrm{a}} \mathrm{P}<0.05,{ }^{\mathrm{b}} \mathrm{P}<0.01,{ }^{\mathrm{c}} \mathrm{P}<0.001 .{ }^{\mathrm{d}} \mathrm{D}$ ata are presented as the mean \pm standard deviation or $\mathrm{n}(\%)$. ${ }^{\mathrm{e}} \mathrm{P}$-values are for the comparison between baseline and 6 months after tenofovir alafenamide switching. ALP, alkaline phosphatase; ALT, alanine aminotransferase; AST, aspartate aminotransferase; BAP, bone specific alkaline phosphatase; HBeAg, hepatitis B e antigen; HBsAg, hepatitis B surface antigen; HBV, hepatitis B virus; N/A, not available.

with a history of LAM and ADV treatment were included in the long-term group. Other significant differences were found in the rates of hypertension (9 vs. $2 ; \mathrm{P}<0.191)$ complications and $\mathrm{HBeAg}$-positive (3 vs. 8; $\mathrm{P}=0.0240$ ). Conversely, no significant differences were found in the other baseline characteristics amongst the two groups.

Time course observation of virological markers and hepatobiliary enzymes. Table II shows the time course of virological markers and hepatobiliary enzymes in all 33 cases after 3 and 6 months after switching to TAF. Regarding virological markers, HBsAg significantly decreased after 6 months $(1,126 \pm 1,724$ to $1,001 \pm 1,591 \mathrm{IU} / \mathrm{ml} ; \mathrm{P}<0.0001)$. As for hepatobiliary enzymes, the serum ALP levels significantly improved $(320 \pm 126$ to $283 \pm 124 \mathrm{U} / \mathrm{l} ; \mathrm{P}=0.028)$. In addition, the serum bone specific alkaline phosphatase (BAP) level, an ALP isozyme derived from bone $(25,26)$, also improved after 6 months $(19.7 \pm 9.0$ to $17.7 \pm 8.0 \mu \mathrm{g} / \mathrm{l} ; \mathrm{P}=0.0006)$. Other virological markers and hepatobiliary enzymes did not show any significant changes.

Time course of observation of renal and tubular function and phosphorus metabolism. Table III shows the time course of renal and tubular functions and phosphorus metabolism in all 33 cases. U-BMG/Cr, which is associated with tubular function, was significantly improved after 6 months $(5,224 \pm 17,471$ to $3,547 \pm 14,652 \mu \mathrm{g} / \mathrm{g} \times \mathrm{Cre} ; \mathrm{P}=0.002)$. Regarding other renal and tubular functions, no significant changes in phosphorus metabolism were noted, and no problematic adverse reactions were observed after switching treatment regimens.

Comparison based on the duration of NA administration. Changes in viral markers, hepatobiliary enzymes, renal and tubular functions, and phosphorus metabolism between the long-term and short-term administration groups were compared and assessed. The results of each group are shown in Tables II and III. In the long-term group, the serum HBsAg levels were $590 \pm 641$ and $537 \pm 598 \mathrm{IU} / \mathrm{ml}$ before switching to TAF and 6 months after switching, respectively $(\mathrm{P}=0.0108)$, and those of the short-term group were $1,853 \pm 2,400$ and $1,631 \pm 2,235 \mathrm{IU} / \mathrm{ml}$, respectively $(\mathrm{P}=0.0040)$. In the long-term group, the serum ALP levels were $324 \pm 141$ and $302 \pm 151 \mathrm{U} / 1$ before switching and 6 months after switching, respectively $(\mathrm{P}=0.0281)$, and those of the short-term group were $298 \pm 86$ and $257 \pm 69 \mathrm{U} / 1$, respectively $(\mathrm{P}=0.0050)$. In the long-term group, the serum BAP levels were $21.1 \pm 11.0$ and $19.2 \pm 9.7 \mu \mathrm{g} / 1$ 
Table III. Time course observation of renal and tubular function, and phosphorus metabolism.

\begin{tabular}{|c|c|c|c|c|}
\hline Parameters $^{\mathrm{b}}$ & Baseline & 3 months & 6 months & P-value ${ }^{c}$ \\
\hline \multicolumn{5}{|l|}{ Total, $n=33$} \\
\hline Creatinine, mg/dl & $0.8 \pm 0.2$ & $0.8 \pm 0.2$ & $0.8 \pm 0.2$ & 0.0744 \\
\hline $\mathrm{eGFR}, \mathrm{ml} / \mathrm{min} / 1.73 \mathrm{~m}^{2}$ & $73.4 \pm 13.7$ & $75.2 \pm 21.7$ & $75.8 \pm 20.9$ & 0.1047 \\
\hline Serum $\mathrm{Ca}, \mathrm{mmol} / \mathrm{l}$ & $9.3 \pm 0.4$ & $9.2 \pm 0.4$ & $9.3 \pm 0.4$ & 0.4241 \\
\hline Serum P, mmol/l & $3.1 \pm 0.5$ & $3.1 \pm 0.4$ & $3.1 \pm 0.5$ & 0.9165 \\
\hline $\mathrm{U}-\mathrm{BMG} / \mathrm{Cr}, \mu \mathrm{g} / \mathrm{g} \cdot \mathrm{Cre}$ & $5,224 \pm 17,471$ & $3,702 \pm 13,769$ & $3,547 \pm 14,652$ & $0.002^{\mathrm{a}}$ \\
\hline $\mathrm{U}-\mathrm{NAG} / \mathrm{Cr}, \mathrm{U} / \mathrm{g} \cdot \mathrm{Cre}$ & $9.2 \pm 8.9$ & $8.8 \pm 10.2$ & $9.2 \pm 9.5$ & 0.8068 \\
\hline$\% \mathrm{TRP}$ & $85.0 \pm 9.3$ & $84.0 \pm 10.0$ & $85.8 \pm 8.8$ & 0.3750 \\
\hline $\mathrm{TmP} / \mathrm{GFR}, \mathrm{mg} / \mathrm{dl}$ & $2.6 \pm 0.6$ & $2.6 \pm 0.5$ & $2.6 \pm 0.6$ & 0.8476 \\
\hline \multicolumn{5}{|l|}{ Long-term group, $n=19$} \\
\hline Creatinine, $\mathrm{mg} / \mathrm{dl}$ & $0.9 \pm 0.3$ & $0.9 \pm 0.2$ & $0.8 \pm 0.2$ & 0.0890 \\
\hline $\mathrm{eGFR}, \mathrm{ml} / \mathrm{min} / 1.73 \mathrm{~m}^{2}$ & $68.4 \pm 17.5$ & $69.9 \pm 17.8$ & $70.9 \pm 17.4$ & 0.1719 \\
\hline Serum Ca, mmol/l & $9.4 \pm 0.4$ & $9.3 \pm 0.4$ & $9.3 \pm 0.3$ & 0.4880 \\
\hline Serum P, mmol/l & $3.1 \pm 0.6$ & $3.1 \pm 0.4$ & $3.0 \pm 0.4$ & 0.7553 \\
\hline $\mathrm{U}-\mathrm{BMG} / \mathrm{Cr}, \mu \mathrm{g} / \mathrm{g} \cdot \mathrm{Cre}$ & $8,636 \pm 23,026$ & $6,191 \pm 17,858$ & $5,815 \pm 19,200$ & $0.0017^{\mathrm{a}}$ \\
\hline $\mathrm{U}-\mathrm{NAG} / \mathrm{Cr}, \mathrm{U} / \mathrm{g} \cdot \mathrm{Cre}$ & $10.8 \pm 11.5$ & $11.1 \pm 13.1$ & $10.8 \pm 12.1$ & 0.7575 \\
\hline$\% \mathrm{TRP}$ & $82.5 \pm 11.4$ & $81.2 \pm 12.0$ & $85.0 \pm 10.7$ & 0.0602 \\
\hline $\mathrm{TmP} / \mathrm{GFR}, \mathrm{mg} / \mathrm{dl}$ & $2.6 \pm 0.7$ & $2.5 \pm 0.6$ & $2.6 \pm 0.5$ & 0.8673 \\
\hline \multicolumn{5}{|l|}{ Short-term group, $n=14$} \\
\hline Creatinine, mg/dl & $0.8 \pm 0.2$ & $0.8 \pm 0.2$ & $0.7 \pm 0.2$ & 0.5409 \\
\hline $\mathrm{eGFR}, \mathrm{ml} / \mathrm{min} / 1.73 \mathrm{~m}^{2}$ & $77.9 \pm 18.1$ & $79.0 \pm 22.2$ & $82.5 \pm 24.0$ & 0.3997 \\
\hline Serum Ca, mmol/l & $9.3 \pm 0.2$ & $9.2 \pm 0.4$ & $9.2 \pm 0.4$ & 0.7471 \\
\hline Serum P, mmol/l & $3.1 \pm 0.5$ & $3.1 \pm 0.4$ & $3.1 \pm 0.7$ & 0.5535 \\
\hline $\mathrm{U}-\mathrm{BMG} / \mathrm{Cr}, \mu \mathrm{g} / \mathrm{g} \cdot \mathrm{Cre}$ & $951 \pm 1,455$ & $262 \pm 179$ & $469 \pm 549$ & $0.0052^{\mathrm{a}}$ \\
\hline U-NAG/Cr, U/g·Cre & $7.2 \pm 3.1$ & $5.6 \pm 2.1$ & $7.0 \pm 3.5$ & 1.0000 \\
\hline$\% \mathrm{TRP}$ & $88.1 \pm 4.5$ & $87.5 \pm 3.9$ & $87.0 \pm 5.4$ & 0.2958 \\
\hline TmP/GFR, mg/dl & $2.7 \pm 0.5$ & $2.7 \pm 0.4$ & $2.7 \pm 0.7$ & 0.9875 \\
\hline
\end{tabular}

${ }^{\mathrm{a}} \mathrm{P}<0.01$. ${ }^{\mathrm{b}} \mathrm{Data}$ are presented as the mean \pm standard deviation. ${ }^{\mathrm{C}} \mathrm{P}$-values are for the comparison between baseline and 6 months after tenofovir alafenamide switching. Ca, calcium; eGFR, estimated glomerular filtration rate; GFR, glomerular filtration rate; P, phosphate; TRP, tubular reabsorption of phosphate; $\mathrm{U}-\mathrm{BMG} / \mathrm{Cr}$, urine $\beta 2$-microglobulin-creatinine ratio; $\mathrm{U}-\mathrm{NAG} / \mathrm{Cr}$, urine $\mathrm{N}$-acetyl- $\beta$-D-glucosaminidase-creatinine ratio.

before switching and 6 months after, respectively $(\mathrm{P}=0.0678)$, whereas in the short-term group, the values were $17.9 \pm 5.1$ and $15.5 \pm 4.6 \mu \mathrm{g} / 1$, respectively $(\mathrm{P}=0.0016)$. In the long-term group, the U-BMG/Cr ratios before switching and 6 months after switching were $8,635 \pm 23,026$ and 5,815 $\pm 19,200 \mu \mathrm{g} / \mathrm{g} \cdot$ Cre, respectively $(\mathrm{P}=0.0017)$, whereas in the short-term group they were $951 \pm 1,455$ and $469 \pm 549 \mu \mathrm{g} / \mathrm{g} \cdot$ Cre, respectively $(\mathrm{P}=0.0052)$.

Fig. 1 shows the reduction in the HBsAg levels and the improvements in serum ALP, serum BAP and U-BMG/Cr levels in each group. The HBsAg levels decreased by $0.88 \pm 1.37$ $\log -\mathrm{IU} / \mathrm{ml}$ in the long-term group and by $1.55 \pm 1.49 \mathrm{log}-\mathrm{IU} / \mathrm{ml}$ in the short-term group, whereas the serum ALP levels improved by $8.1 \pm 11.9 \%$ in the long-term group and $12.2 \pm 12.8 \%$ in the short-term group. The serum BAP levels improved by $6.5 \pm 17.1 \%$ in the long-term group and $12.2 \pm 12.0 \%$ in the short-term group. U-BMG/Cr improved by $40.6 \pm 42.9 \%$ in the long-term group and by $32.1 \pm 34.3 \%$ in the short-term group. In summary, similar to the results seen in all 33 cases, a significant decrease in serum HBsAg levels and a significant improvement in serum ALP and U-BMG/Cr levels were observed in both groups. The serum BAP improved in both groups, but a significant improvement was observed only in the short-term group. HBsAg was significantly reduced in the short-term group compared with the long-term group $(\mathrm{P}=0.0432)$. No significant differences were found between the two groups in the other comparisons.

\section{Discussion}

The present study evaluated changes in biochemical (particularly renal and tubular functions and phosphorus metabolism) and virological markers in patients with $\mathrm{CHB}$ who switched from treatment with ADV or TDF therapy to TAF therapy. The results from the whole sample showed that the serum HBsAg and ALP levels and the U-BMG/Cr ratio were significantly decreased 6 months after switching. Within this period, no cases were found to have inadequate disease control 

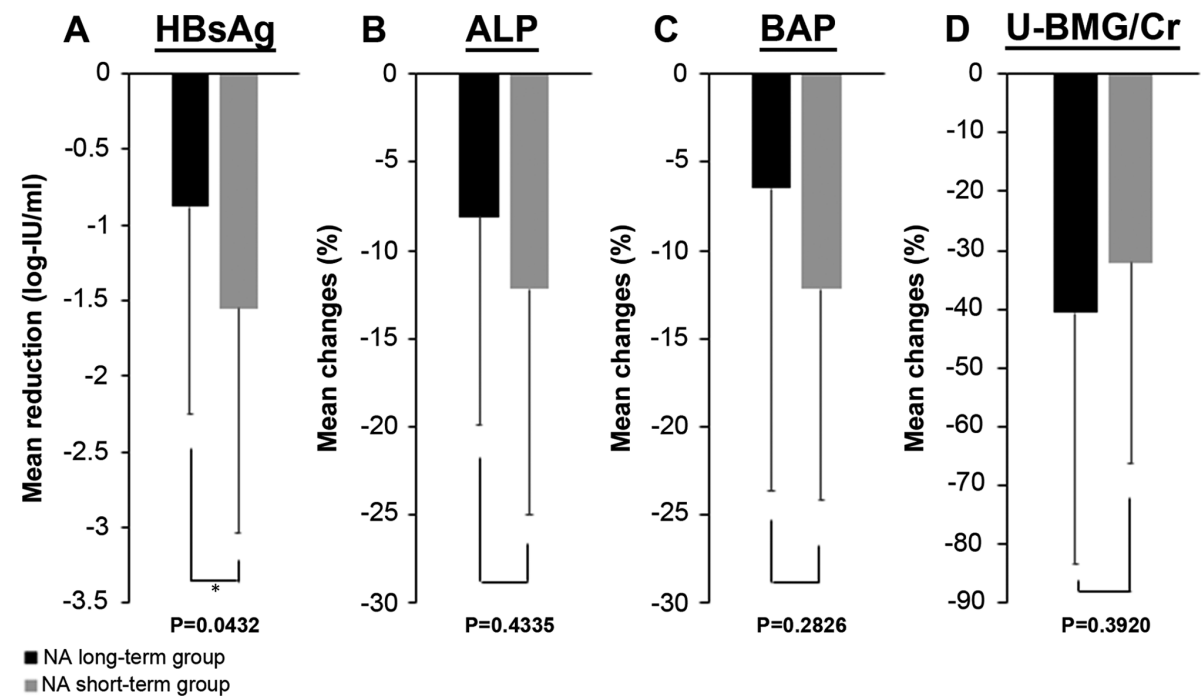

Figure 1. Mean reduction or improvement rate from baseline to 6 months after tenofovir alafenamide switching between the NA long-term group and the short-term group. Results of (A) serum HBsAg levels, (B) serum ALP levels, (C) serum BAP levels and (D) U-BMG/Cr levels. "P<0.05. ALP, alkaline phosphatase; BAP, bone specific alkaline phosphatase; HBsAg, hepatitis B surface antigen; NA, nucleos(t)ide analogs; U-BMG/Cr, urine $\beta 2$-microglobulin-creatinine ratio.

due to a decrease in the antiviral effect and exacerbation of hepatobiliary enzymes.

Regarding the reduction in the HBsAg levels, Hagiwara et al (27) reported that it was particularly prominent in patients with serum HBsAg levels $<800 \mathrm{IU} / \mathrm{ml}$ after switching from ETV to TAF. Uchida et al (28) found that the degree of reduction in serum HBsAg levels after switching from ETV to TAF was significantly higher, particularly in patients with cirrhosis, genotype B HBV infection and serum hepatitis B core related antigen levels $<3.0 \log \mathrm{U} / \mathrm{ml}$. As mentioned above, some studies reported on factors contributing to the reduction in the serum HBsAg levels after switching from other NAs to TAF. In patients with low levels of HBV DNA who had a low risk of HCC, serum HBsAg levels were identified as an independent risk factor for the development of HCC (29). In addition, patients who received TDF treatment exhibit a reduced risk of developing HCC compared with those who received ETV treatment $(30,31)$.

A possible mechanism underlying the difference in HCC risk is the induction of IFN- $\lambda$ activity in patients treated with NAs, such as TDF and TAF, which would lead to the inhibition of HBsAg production and activation of an antitumor effect (32). As mentioned above, since the inhibitory effect of TFV on HCC development has been reported, it is necessary to examine not only the effect of reducing serum HBsAg levels in TAF but also the effect of reducing HCC risk in the future, but this was not evaluated in the present study. Moreover, renal and tubular functions were considered. Mitochondrial dysfunction of the proximal tubule cells is presumed to be a mechanism of renal dysfunction and the onset of ADV-related Fanconi syndrome (33). Fanconi syndrome is a disease that causes disorders of glucose, amino acid, phosphorus, and bicarbonate reabsorption in the proximal tubule of the kidney, and is often associated with osteomalacia (34). Renal tubular injury is characterized by a decrease in serum phosphorus and uric acid levels, an increase in U-BMG, and osteomalacia combined with elevation of the serum ALP levels $(34,35)$. Previously, genetic polymorphisms of multidrug resistance-associated protein 2 , which is involved in the excretion of ADV from the renal tubule, have been reported as factors contributing to renal impairment by ADV (36,37). Although ADV was changed to TDF in ADV-related Fanconi syndrome, TDF is structurally similar to ADV, and renal dysfunction and Fanconi syndrome due to TDF have also been reported. Therefore, as in ADV treatment, monitoring of renal and tubular functions is also required $(17,18,38)$.

As an important clinical premise, tubular dysfunction may precede the decline in glomerular function. Tubular proteinuria implies the presence of increased amounts of small-sized proteins in the urine that are freely filtered in the glomerulus but reabsorbed by the proximal tubules $(39,40)$. $\beta 2$-microglobulinuria is prevalent amongst TFV-treated patients, even with normal GFR $(39,40)$. In the present study, the mean overall eGFR was $73.4 \pm 13.7 \mathrm{ml} / \mathrm{min} / 1.73 \mathrm{~m}^{2}$; although various patients had normal kidney function or mild CKD, the mean U-BMG/Cr was elevated $(>300 \mu \mathrm{g} / \mathrm{g} \cdot$ Cre was defined as abnormal) (41), indicating that tubular damage was already present. Primary tubular abnormalities, even severe, may be missed until they affect the glomerular function; thus, specific and early screening is necessary to prevent abnormalities.

Blood biochemical examination alone is insufficient to assess tubular dysfunction, and a regular urine test is recommended in patients undergoing NA treatment. This is also useful for evaluating phosphorous metabolism. Thus, how the duration of NA administration affected the transition of biochemical data was assessed with a focus on renal and tubular function after switching to TAF between the long-term and short-term groups. The U-BMG/Cr findings indicate that tubular injury was already present even in the short-term group. Similar to the whole-sample results, switching to TAF showed a significant improvement in serum ALP levels and in the U-BMG/Cr ratio in both groups. As shown in Fig. 1, an improvement in serum ALP levels and in the U-BMG/Cr ratio can be expected after this switch.

The important points of the present study were that these improvements were obtained regardless of the duration of the previous NA administration and that the effect was observed within 6 months after switching therapy. The incidence of tubular dysfunction has been reported to increase dramatically 
8 years after the start of ADV administration (42). Thus, it is notable that the tubular dysfunction caused by long-term administration of NA, including ADV, is improved by switching to TAF. A real-world study also reported that switching from TDF to TAF significantly reduced tubular dysfunction markers, including the U-BMG/Cr and retinol-binding protein-creatinine ratio in 3 months (43). A previous study also reported that not only tubular dysfunction markers, but also eGFR, significantly improved 1 and 6 months after switching from TDF to TAF (44).

Most patients treated with NA combination therapy have already been treated for years or even decades. Furthermore, since complete eradication of HBV is exceedingly difficult with current treatments, continuous treatment is required. Based on previous reports and the present study, which found an improvement in a short period of time, switching to TAF in patients with renal and tubular dysfunction appears to be effective regardless of previous NA administration duration $(43,44)$. Therefore, switching to TAF should be considered, even in patients treated with NAs who have not experienced side effects. Although a detailed examination was not performed in the present study, including analysis of changes in bone density, the improvement in serum ALP and BAP levels may reflect an improvement in bone metabolism. In fact, clinical trials and real-world studies have shown superior bone safety in patients treated with TAF compared with those treated with TDF (4-6,43).

The limitations of the present study are the small sample size, the short-term follow-up period, and the lack of a control group. The effects on serum HBsAg level reduction, renal tubular function and bone metabolism by switching from NA to TAF should be investigated in a larger cohort over a period of time. Considering the association between renal and bone dysfunction, long-term administration of ADV and TDF, and the increase in compliance due to the convenience of administration timing compared with ETV (45), if the antiviral effect is not inferior in the long term and is safer, it is expected that switching to TAF therapy will become more frequently recommended in the future. Further randomized clinical trials are required for selecting appropriate NAs.

In conclusion, switching from ADV or TDF to TAF confirmed a decrease in serum HBsAg and improvement in serum ALP levels and the U-BMG/Cr ratio after 6 months in patients regardless of length of NA administration history.

\section{Acknowledgements}

The authors would like to thank Dr T. Kawaguchi, Dr T. Nakamura, Dr M. Nakano, Dr S. Okamura, Dr M. Abe and Dr S. Shimose, Division of Gastroenterology, Department of Internal Medicine, Kurume University School of Medicine for their contribution to this study.

\section{Funding}

No funding was received.

\section{Availability of data and materials}

The datasets used and/or analyzed during the present study are available from the corresponding author on reasonable request.

\section{Authors' contributions}

TS, KA, TI, TK, RK, TAH, HK, RK and TT obtained the biological samples. TS, KA, and TI analyzed the data. TS wrote the manuscript. All authors read and approved the final manuscript.

\section{Ethics approval and consent to participate}

This study was performed in accordance with the ethical principles of the Declaration of Helsinki and was approved by the Clinical Research Ethics Committee of Kurume University Hospital (approval no. 17209). Written informed consent was obtained from all patients.

\section{Patient consent for publication}

Not applicable.

\section{Competing interests}

The authors declare that they have no competing interests.

\section{References}

1. Trépo C, Chan HLY and Lok A: Hepatitis B virus infection. Lancet 384: 2053-2063, 2014

2. Kwon H and Lok AS: Hepatitis B therapy. Nat Rev Gastroenterol Hepatol 8: 275-284, 2011.

3. Lo AO and Wong GL: Current developments in nucleoside/nucleotide analogues for hepatitis B. Expert Rev Gastroenterol Hepatol 8: 607-622, 2014.

4. Buti M, Gane E, Seto WK, Chan HL, Chuang WL, Stepanova T, Hui AJ, Lim YS, Mehta R, Janssen HL, et al: Tenofovir alafenamide versus tenofovir disoproxil fumarate for the treatment of patients with $\mathrm{HBeAg-negative} \mathrm{chronic} \mathrm{hepatitis} \mathrm{B} \mathrm{virus} \mathrm{infec-}$ tion: A randomised, double- blind, phase 3 , non-inferiority trial. Lancet Gastroenterol Hepatol 1: 196-206, 2016.

5. Chan HL, Fung S, Seto WK, Chuang WL, Chen CY, Kim HJ, Hui AJ, Janssen HL, Chowdhury A, Tsang TY, et al: Tenofovir alafenamide versus tenofovir disoproxil fumarate for the treatment of $\mathrm{HBeAg}$-positive chronic hepatitis B virus infection: A randomised, double-blind, phase 3, non-inferiority trial. Lancet Gastroenterol Hepatol 1: 185-195, 2016.

6. Agarwal K, Brunetto M, Seto WK, Lim YS, Fung S, Marcellin P, Ahn SH, Izumi N, Chuang WL, Bae H, et al: 96 weeks treatment of tenofovir alafenamide vs. tenofovir disoproxil fumarate for hepatitis B virus infection. J Hepatol 68: 672-681, 2018.

7. Wong GL, Chan HL, Mak CW, Lee SK, Ip ZM, Lam AT, Iu HW, Leung JM, Lai JW, Lo AO, et al: Entecavir treatment reduces hepatic events and deaths in chronic hepatitis B patients with liver cirrhosis. Hepatology 58: 1537-1547, 2013.

8. Gordon SC, Lamerato LE, Rupp LB, Li J, Holmberg SD, Moorman AC, Spradling PR, Teshale EH, Vijayadeva V, Boscarino JA, et al: Antiviral therapy for chronic hepatitis B virus infection and development of hepatocellular carcinoma in a US population. Clin Gastroenterol Hepatol 12: 885-893, 2014.

9. Lok AS, McMahon BJ, Brown RS Jr, Wong JB, Ahmed AT, Farah W, Almasri J, Alahdab F, Benkhadra K, Mouchli MA, et al: Antiviral therapy for chronic hepatitis B viral infection in adults: A systematic review and meta-analysis. Hepatology 63: 284-306, 2016.

10. Mak LY, Seto WK, Lai CL and Yuen MF: DNA polymerase inhibitors for treating hepatitis B: A safety evaluation. Expert Opin Drug Saf 15: 383-392, 2016.

11. Wong GL, Tse YK, Wong VW, Yip TC, Tsoi KK and Chan HL: Long-term safety of oral nucleos(t)ide analogs for patients with chronic hepatitis B: A cohort study of 53,500 subjects. Hepatology 62: 684-693, 2015.

12. Cathcart AL, Chan HL, Bhardwaj N, Liu Y, Marcellin P, Pan CQ, Shalimar, Buti M, Cox S, Parhy B, et al: No resistance to tenofovir alafenamide detected through 96 Weeks of treatment in patients with chronic hepatitis B infection. Antimicrob Agents Chemother 62: e01064-18,2018. 
13. Sax PE, Wohl D, Yin MT, Post F, DeJesus E, Saag M, Pozniak A, Thompson M, Podzamczer D, Molina JM, et al: Tenofovir alafenamide versus tenofovir disoproxil fumarate, coformulated with elvitegravir, cobicistat, and emtricitabine, for initial treatment of HIV-1 infection: Two randomised, double-blind, phase 3 non-inferiority trials. Lancet 385: 2606-2615, 2015.

14. Mills A, Arribas JR, Andrade-Villanueva J, DiPerri G, Van Lunzen J, Koenig E, Elion R, Cavassini M, Madruga JV, Brunetta $\mathrm{J}$, et al: Switching from tenofovir disoproxil fumarate to tenofovir alafenamide in antiretroviral regimens for virologically suppressed adults with HIV-1 infection: A randomised, active-controlled, multicentre, open-label, Phase 3, non-inferiority study. Lancet Infect Dis 16: 43-52, 2016.

15. Agarwal K, Fung SK, Nguyen TT, Cheng W, Sicard E, Ryder SD, Flaherty JF, Lawson E, Zhao S, Subramanian GM, et al: Twenty-eight days safety, antiviral activity, and pharmacokinetics of tenofovir alafenamide for treatment of chronic hepatitis B infection. J Hepatol 62: 533-540, 2015.

16. Ha NB, Ha NB, Garcia RT, Trinh HN, Vu AA, Nguyen HA, Nguyen KK, Levitt BS and Nguyen MH: Renal dysfunction in chronic hepatitis B patients treated with adefovir dipivoxil. Hepatology 50: 727-734, 2009.

17. Jung YK, Yeon JE, Choi JH, Kim CH, Jung ES, Kim JH, Park JJ, Kim JS, Bak YT and Byun KS: Fanconi's Syndrome associated with prolonged adefovir dipivoxil therapy in a hepatitis B virus patient. Gut Liver 4: 389-393, 2010.

18. Viganò M, Brocchieri A, Spinetti A, Zaltron S, Mangia G, Facchetti F, Fugazza A, Castelli F, Colombo M and Lampertico P: Tenofovir-induced Fanconi syndrome in chronic hepatitis B monoinfected patients that reverted after tenofovir withdrawal. J Clin Virol 61: 600-603, 2014

19. Mauss S, Berger F, Filmann N, Hueppe D, Henke J, Hegener P Athmann C, Schmutz G and Herrmann E: Effect of HBV polymerase inhibitors on renal function in patients with chronic hepatitis B. J Hepatol 55: 1235-1240, 2011.

20. World Medical Association Declaration of Helsinki: Ethical principles for medical research involving human subjects. JAMA 310: 2191-2194, 2013

21. Drafting Committee for Hepatitis Management Guidelines and the Japan Society of Hepatology. JSH Guidelines for the management of hepatitis B virus infection. Hepatol Res 44 (Suppl S1) S1-S58, 2014

22. Committee of the Japan Diabetes Society on the Diagnostic Criteria of Diabetes Mellitus, Seino Y, Nanjo K, Tajima N, Kadowaki T, Kashiwagi A, Araki E, Ito C, Inagaki N, Iwamoto Y, et al: Report of the committee on the classification and diagnostic criteria of diabetes mellitus. J Diabetes Investig 1: 212-228, 2010

23. Levey AS, Stevens LA, Schmid CH, Zhang Y, Castro AF III, Feldman HI, Kusek JW, Eggers P, Van Lente F, Greene T, et al: A new equation to estimate glomerular filtration rate. Ann Intern Med 150: 604-612, 2009.

24. Barth JH, Jones RG and Payne RB: Calculation of renal tubular reabsorption of phosphate: The algorithm performs better than the nomogram. Ann Clin Biochem 37: 79-81, 2000.

25. Bervoets AR, Spasovski GB, Behets GJ, Dams G, Polenakovic MH, Zafirovska K, Van Hoof VO, De Broe ME and D'Haese PC: Useful biochemical markers for diagnosing renal osteodystrophy in predialysis end-stage renal failure patients Am J Kidney Dis 41: 997-1007, 2003.

26. Ureña P, Hruby M, Ferreira A, Ang KS and de Vernejoul MC: Plasma total versus bone alkaline phosphatase as markers of bone turnover in hemodialysis patients. J Am Soc Nephrol 7: 506-512, 1996

27. Hagiwara S, Nishida N, Ida H, Ueshima K, Minami Y, Takita M, Komeda Y and Kudo M: Switching from entecavir to tenofovir alafenamide versus maintaining entecavir for chronic hepatitis B. J Med Virol 91: 1804-1810, 2019.

28. Uchida Y, Nakao M, Tsuji S, Uemura H, Kouyama JI, Naiki K, Motoya D, Sugawara K, Nakayama N, Imai Y, et al: Significance of switching of the nucleos(t)ide analog used to treat Japanese patients with chronic hepatitis B virus infection from entecavir to tenofovir alafenamide fumarate. J Med Virol 92: 329-338, 2020.

29. Tseng TC, Liu CJ, Yang HC, Su TH, Wang CC, Chen CL, Kuo SF, Liu CH, Chen PJ, Chen DS and Kao JH: High levels of hepatitis B surface antigen increase risk of hepatocellular carcinoma in patients with low HBV load. Gastroenterology 142: 1140-1149.e3; quiz e13-4, 2012.
30. Choi J, Kim HJ, Lee J, Cho S, Ko MJ and Lim YS: Risk of hepatocellular carcinoma in patients treated with entecavir vs. tenofovir for chronic hepatitis B: A Korean nationwide cohort study. JAMA Oncol 5: 30-36, 2019.

31. Yip TC, Wong VW, Chan HL, Tse YK, Lui GC and Wong GL: Tenofovir is associated with lower risk of hepatocellular carcinoma than entecavir in patients with chronic HBV infection in China. Gastroenterology 158: 215-225.e6, 2019.

32. Murata K, Asano M, Matsumoto A, Sugiyama M, Nishida N, Tanaka E, Inoue T, Sakamoto M, Enomoto N, Shirasaki T, et al: Induction of IFN- $\lambda 3$ as an additional effect of nucleotide, not nucleoside, analogues: A new potential target for HBV infection. Gut 67: 362-371, 2018.

33. Tanji N, Tanji K, Kambham N, Markowitz GS, Bell A and D'agati VD: Adefovir nephrotoxicity: Possible role of mitochondrial DNA depletion. Hum Pathol 32: 734-740, 2001.

34. Izzedine $\mathrm{H}$, Launay-Vacher V, Isnard-Bagnis $\mathrm{C}$ and Deray G: Drug-induced Fanconi's syndrome. Am J Kidney Dis 41: 292-309, 2003

35. Sun L, Yi D, Sun W and Wang C: Retrospective analysis of the clinical characteristics of adefovir dipivoxil-induced Fanconi's syndrome in the Chinese population. J Clin Pharm Ther 45: $722-728,2020$

36. Servais A, Lechat P, Zahr N, Urien S, Aymard G, Jaudon MC, Deray $\mathrm{G}$ and Isnard Bagnis C: Tubular transporters and clearance of adefovir. Eur J Pharmacol 540: 168-174, 2006

37. Sanyal A, Bass N, Mullen K, Poordad F, Shaw A, Merchant K, Bortey E, Forbes WP and Huang S: A drug transporter gene polymorphism predicts renal tubular toxicity in patients with chronic hepatitis B on long-term adefovir and lamivudine combination. J Hepatol 52: S7, 2010

38. Fernandez-Fernandez B, Montoya-Ferrer A, Sanz AB Sanchez-Niño MD, Izquierdo MC, Poveda J, Sainz-Prestel V, Ortiz-Martin N, Parra-Rodriguez A, Selgas R, et al: Tenofovir nephrotoxicity: 2011 update. AIDS Res Treat 2011: 354908, 2011.

39. Papaleo A, Warszawski J, Salomon R, Jullien V, Veber F, Dechaux $M$ and Blanche S: Increased beta-2 microglobulinuria in human immunodeficiency virus-1-infected children and adolescents treated with tenofovir. Pediatr Infect Dis J 26: 949-951, 2007.

40. Gatanaga H, Tachikawa N, Kikuchi Y, Teruya K, Genka I, Honda M, Tanuma J, Yazaki H, Ueda A, Kimura S and Oka S: Urinary beta2-microglobulin as a possible sensitive marker for renal injury caused by tenofovir disoproxil fumarate. AIDS Res Hum Retroviruses 22: 744-748, 2006.

41. Dauchy FA, Lawson-Ayayi S, de La Faille R, Bonnet F, Rigothier C, Mehsen N, Miremont-Salamé G, Cazanave C, Greib C, Dabis F and Dupon M: Increased risk of abnormal proximal renal tubular function with HIV infection and antiretroviral therapy. Kidney Int 80: 302-309, 2011.

42. Shimizu M, Furusyo N, Ikezaki H, Ogawa E, Hayashi T, Ihara T, Harada Y, Toyoda K, Murata M and Hayashi J: Predictors of kidney tubular dysfunction induced by adefovir treatment for chronic hepatitis B. World J Gastroenterol 21: 2116-2123, 2015.

43. Fong TL, Lee BT, Tien A, Chang M, Lim C, Ahn A and Bae HS: Improvement of bone mineral density and markers of proximal renal tubular function in chronic hepatitis B patients switched from tenofovir disoproxil fumarate to tenofovir alafenamide. J Viral Hepat 26: 561-567, 2019.

44. Kaneko S, Kurosaki M, Tamaki N, Itakura J, Hayashi T, Kirino S, Osawa L, Watakabe K, Okada M, Wang W, et al: Tenofovir alafenamide for hepatitis B virus infection including switching therapy from tenofovir disoproxil fumarate. J Gastroenterol Hepatol 34: 2004-2010, 2019.

45. Tamaki N, Kurosaki M, Nakanishi H, Itakura J, Inada K, Kirino S, Yamashita K, Osawa L, Sekiguchi S, Hayakawa Y, et al: Comparison of medication adherence and satisfaction between entecavir and tenofovir alafenamide therapy in chronic hepatitis B. J Med Virol 92: 1355-1358, 2020.

This work is licensed under a Creative Commons Attribution-NonCommercial-NoDerivatives 4.0 International (CC BY-NC-ND 4.0) License. 